\title{
Characterization of DNA polymorphisms in Caryocar brasiliense (Camb.) in populations with and without thorn at the endocarp by RAPD markers
}

\author{
LUCIANA N. LONDE ${ }^{1}$, CARLOS UEIRA-VIEIRA ${ }^{2}$, WARWICK E. KERR ${ }^{2}$ and ANA MARIA BONETTI ${ }^{2}$ \\ ${ }^{1}$ Empresa de Pesquisa Agropecuária de Minas Gerais (EPAMIG), Laboratório de Biotecnologia \\ Rodovia MGT 122, Km 155, Fazenda Experimental do Gorutuba, 39525-000 Nova Porteirinha, MG, Brasil \\ ${ }^{2}$ Universidade Federal de Uberlândia - Instituto de Genética e Bioquímica \\ Laboratório de Genética, Campus Umuarama, Bloco 2E, sala 33, 38400-902 Uberlândia, MG, Brasil
}

Manuscript received on November 6, 2008; accepted for publication on April 8, 2010

\begin{abstract}
Caryocar brasiliense (pequi), is one of the main species at the biome of the Brazilian savannah due to its use in culinary, popular medicine, industry in general, and iron and steel industry. At São José do Xingu (MT), a tree of C. brasiliense without thorn at the endocarp was found, which enables the improvement of $C$. brasiliense not only for consumption but also to the high appreciation it already has. To detect the existing differences between the pequi with and without the thorn at the endocarp, RADP markers were used. The generated polymorphisms were cloned and sequenced in order to identify the sequences that are responsible for the fenotypical alteration. It was observed that the pequi without thorn is genetically isolated from the other populations of pequi with thorn at the endocarp, proving that this characteristic is related to the genetic divergence of the species. Analysis in BLASTn evidenced the similarity of the Dof1 genes of Zea mays to its gene of phosphinotricin acetyl transferase. In the analysis of BLASTx, the similarity was verified to the proteins responsible for the deficiency in ferric reductase 4 , and catalase.
\end{abstract}

Key words: Caryocar brasiliense, pequi, thorn, RAPD.

\section{INTRODUCTION}

Caryocar brasiliense Camb. (Caryocaraceae), is one of the species that have been highlighted in the biome of the Brazilian savannah (Fig. 1). It is a tree of great importance in the North of Minas, where its fruit harvest is of great relevance for the feeding of the hinterland inhabitants, besides constituting an income source (Araujo 1995, Alencar 2000) (Figs. 2a and 2b).

This species has been highlighting itself by the use of its fruits (mesocarp) in the human feeding in many regions through the preparations by cooking typical dishes and preparing spices, oils and sugar sweetened beverages (Barradas 1972, Corner 1976, Almeida and Silva 1994, Lopes et al. 2003, Santos et al. 2007). It is considered as a source of $\mathrm{A}$ and $\mathrm{C}$ vitamins, thiamine, pro-

Correspondence to: Luciana Nogueira Londe

E-mail: luciana@epamig.br teins and mineral salts, presenting elevated carotenoid tenors. It is also used in oils extraction for the manufacturing of cosmetics (Almeida et al. 1998). In the popular medicine, it is used for the treatment of respiratory and ophtalmic problems, against bronchitis, colds, flus, and in tumors control (Almeida and Silva 1994). It is considered as an aphrodisiac; and its leaves are adstringent, also stimulating the bile production (Almeida and Silva 1994, Ribeiro 1996, Brandão et al. 2002, Kerr et al. 2007). The nut, besides being used in tannery, is tinctorial (Brandão et al. 2002). Its wood has excellent quality and high resistance (Almeida and Silva 1994), and it is a source of coal to iron and steel industries (Ribeiro 1996).

The exploration of the pequi tree is based on fruit harvesting, which characterizes an action of extraction and, as the trend has been to extract the most from it, its possible extinction in the future can be speculated about. 

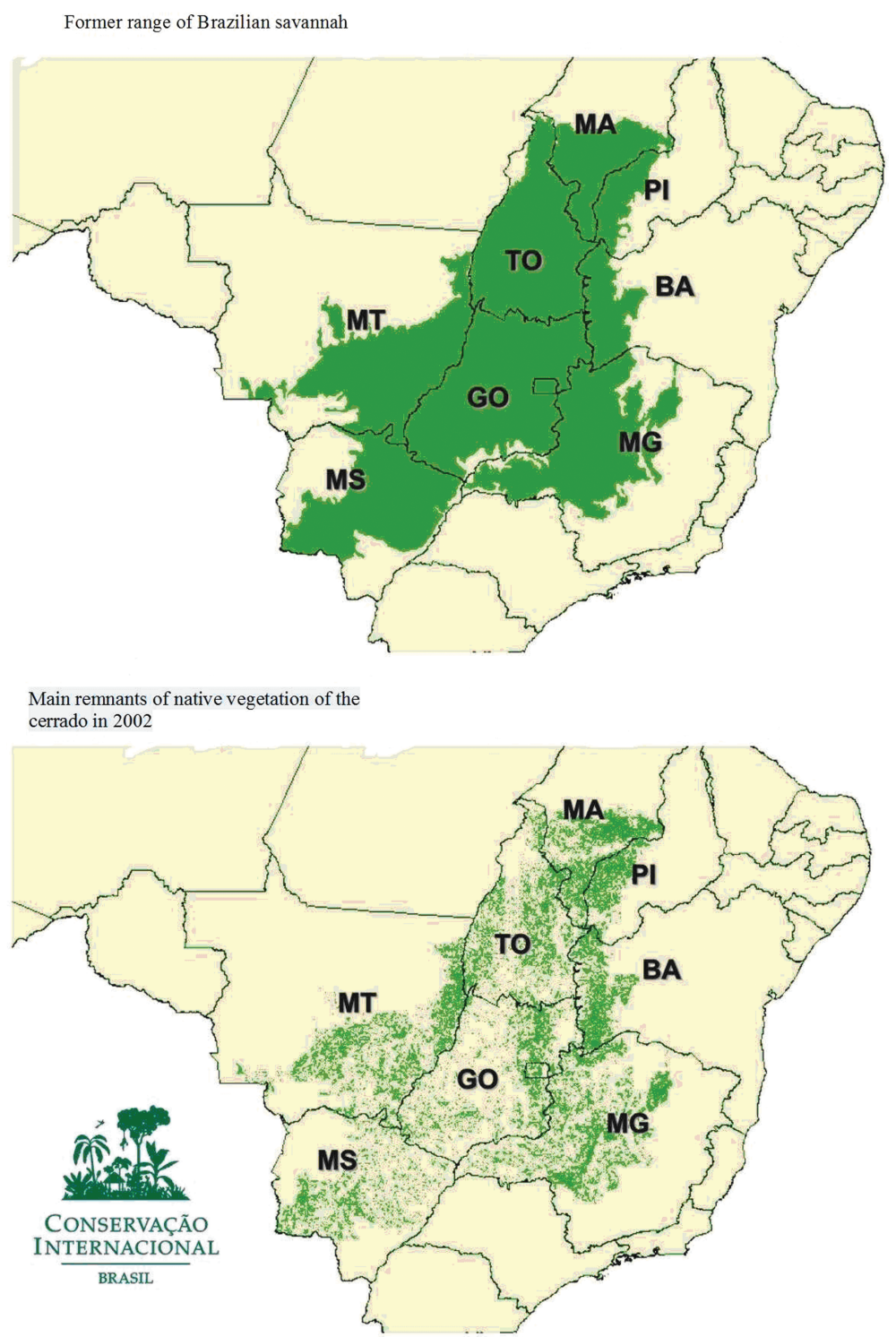

Fig. 1 - Map of Brazilian savannah regions. Source: <http://www.conservation.org.br/arquivos/Mapa\%20desmat\%20Cerrado.jpg>

(A)

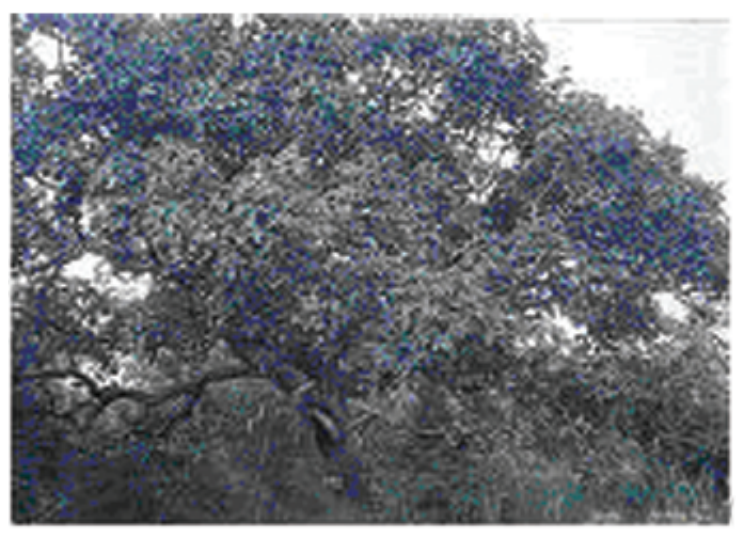

(B)

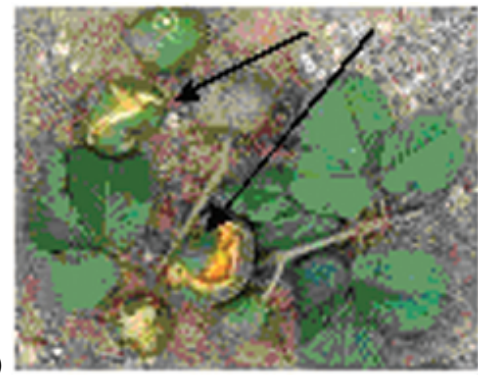

Fig. 2 - Pequi tree (Caryocar brasiliense). (A) Adult plant. (B) Details of the fruit. 
(A)

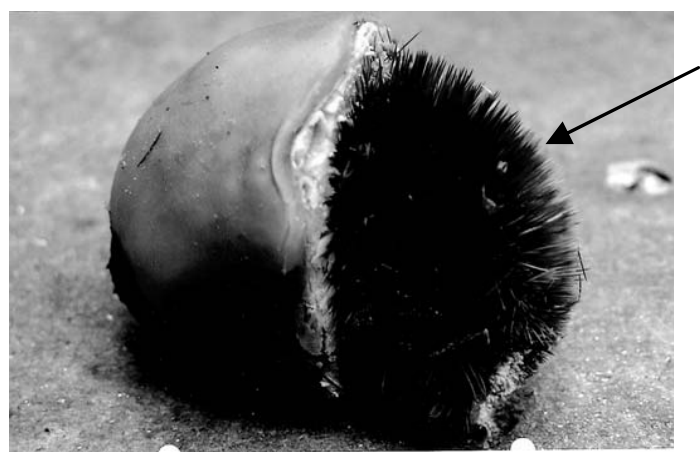

(B)

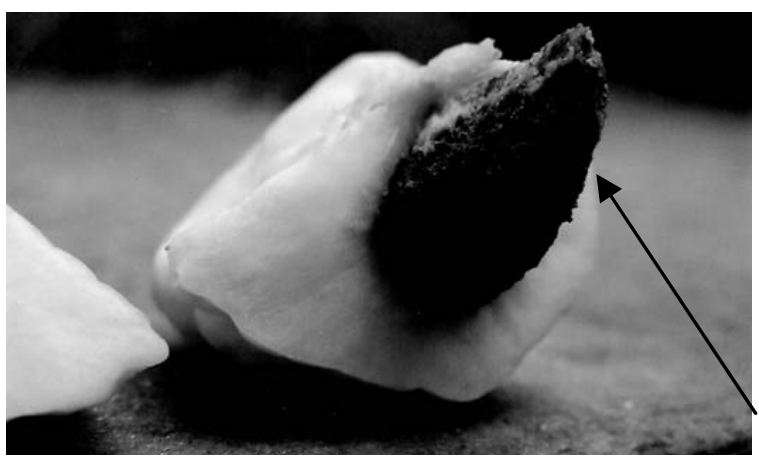

Fig. 3 - Comparison between the pequi with thorn and the one without it at the endocarp. Source: Kerr et al. (2007). (A) Pequi with thorn at the endocarp. Selected fruit showing the endocarp full of little thorns. (B) Pequi without thorn at the endocarp. Selected fruit showing the endocarp without thorns.

The pequi region is spread over almost $2,000 \mathrm{mu}-$ nicipalities, with about 40,000 collectors to sell its fruits or the "seed kernels" to buyers or resellers. The small pharmacies and shamans of the villages and cities of these regions require about 3,000 people to remove the thorns left by the seed kernels at the palate of unaware eaters. This characteristic is the main flaw that eliminates the pequi from being cultivated at home and of being considered as market fruit (R. Gribel, unpublished data, Kerr et al. 2007).

At São José do Xingu, Kerr et al. (2007) interestingly found a plant with an endocarp without seed kernels, producing about 500 fruits on 2004 and only 30 on 2005, and being the "seed kernels" fleshy, a little sweeter than the common ones and much better than the others due to the absence of thorns (Figs. $3 a$ and $3 b$ ).

This fact became a hope for us to have, from 4 to 8 years from now, a distribution of pequi seedlings without thorn at the mesocarp. This "mutation" presents all the characteristics to turn pequi into a market fruit, as much for the poor populations as for the regular markets of national and foreign fruits. It improves pequi not only for a bigger consumption, but also for home harvesting.

Many polymorphisms among pequi populations by using micro-satellites were described. However, the RAPD (Williams et al. 1990) will be used in this paper once it discriminates well the existing polymorphisms among the individuals without thorn from the populations with thorn at the endocarp.

The aim of this paper was to identify standards of polymorphisms by means of RAPD markers, among pe- qui populations with the prickly endocarp and the individuals without thorns.

\section{MATERIALS AND METHODS}

\section{Collection Areas}

Samples of expanded and healthy leaves were collected from 20 individuals from 5 populations of the Brazilian savannah: Clube Caça e Pesca Itororó de Uberlândia - Uberlândia (MG); urban area of Porto Nacional - Tocantins (TO); Fazenda Arrependidos - Corumbaíba (GO); São José do Xingu - Mato Grosso (MT) (populations with thorn) and São José do Xingu - Mato Grosso (MT) (populations without thorn). The leaves were stored in an ultra-freezer $\left(-80^{\circ} \mathrm{C}\right)$ at the Laboratory of Genetics, Institute of Genetics and Biochemistry, Universidade Federal de Uberlândia (MG - Brazil).

\section{GeNOMIC DNA ExtRaction}

The genomic DNA was extracted by the CTAB method with modifications according to Doyle and Doyle (1990) by using "bulks" of the 20 individuals of the populations with and without thorn, separately, with about $1 \mathrm{~g}$ of vegetable tissue.

When homogeneizing the genetic material, the tubes containing the DNA were maintained at the freezer at $-20^{\circ} \mathrm{C}$, being unfreezed only before the use.

The amount of extracted DNA was estimated in spectrophotometer, model GBC-UV/VIS911A (SONY), by reading of absorbance at $260 \mathrm{~nm}$.

Genomic DNA bands, separated by electrophoresis in agarose gel $1.0 \%(\mathrm{p} / \mathrm{v})$, were used as indicators of 
integrity of the extracted DNA. The quantified and evaluated sample was diluted in milli-Q water for the concentration of work of $5 \mathrm{ng} / \mu \mathrm{L}$, and maintained in freezer at $-20^{\circ} \mathrm{C}$.

\section{RAPD REACTION (RANDOM AMPLIFIED POLYMORPHISM DNA)}

In order to evaluate the genetic diversity of the accesses, samples of DNA C. brasiliense leaves with and without thorn were amplified through PCR (Polymerase Chain Reaction) for the obtainment of RAPD markers. The reactions of amplification were made in a volume of $20 \mu \mathrm{L}$, with $2 \mu \mathrm{L}$ of Taq 10X cap, $3 \mu \mathrm{L}$ dNTP $(4 \mathrm{mM}), 1 \mu \mathrm{L}$ $\mathrm{MgCl} 2(2.5 \mathrm{mM}), 1 \mu \mathrm{L}$ of polymerase $\mathrm{Taq}(1 \mathrm{U} / \mathrm{mL})$, $1 \mu \mathrm{L}$ of primer (10 pmoles), $1 \mu \mathrm{L}$ of genomic DNA (5 ng) and $11.8 \mu \mathrm{L}$ of milli-Q water. 77 random primers were used, out of which 53 were selected for presenting better standards of bands (Table I).

The amplifications were done in thermocycler (MJ Research, Inc., model PTC-100), programmed for 40 cycles of 1 minute at $94^{\circ} \mathrm{C}, 1$ minute at $35^{\circ} \mathrm{C}$, and 2 minutes at $72^{\circ} \mathrm{C}$. After the 40 cycles, an extension stage was done with 8 cycles of 20 seconds at $40^{\circ} \mathrm{C}, 7$ minutes at $72^{\circ} \mathrm{C}$, and reduction for $4^{\circ} \mathrm{C}$. After the amplification, in each sample, $2 \mu \mathrm{L}$ of the bromophenol blue mixture $(0.25 \% \mathrm{p} / \mathrm{v})$ and glycerol $(60 \% \mathrm{v} / \mathrm{v})$ were added in water. $15 \mu \mathrm{L}$ of each sample was applied in agarose gel $1.5 \%$, colored with Ethidium Bromide $(0.5 \mu \mathrm{g} / \mathrm{mL})$ and immersed in TBE 0.5X cap (Tris-Borate $90 \mathrm{mM}$, EDTA $1 \mathrm{mM}$ ). The electrophoretic separation was of 3 hours at 120 volts, after what the gels were visualized and photographed in Image Mater ${ }^{\mathrm{TM}}$ VDS Software (Pharmacia Bioscience), and the polymorphic bands were cut under ultraviolet light.

\section{DATA ANALYSIS}

The generated RAPD markers were converted into a matrix of binary data, from which the genetic distances among the different bulks were estimated. The matrix of genetic distance was done for the analysis of genetic diversity by means of the dendogram.

Duplicates of each gel were done and the bands in both gels were analyzed.

The matrix generated by the STATISTICA $4.5 \mathrm{~A}$ (1993) program was used for the calculation of the ge- netic distances and the grouping analysis. The first was calculated by the method of Percentage of Disagreement, which is given by the formula: $\mathrm{N}_{\mathrm{AB}}^{\prime} / \mathrm{N}_{\mathrm{T}}$, where $\mathrm{N}_{\mathrm{AB}}^{\prime}$ is the total number of polymorphic bands among the compared genotypes, and $\mathrm{N}_{\mathrm{T}}$ is the total number of generated bands at the process.

The analysis of groups or clusters was made by the non-ponderated method of grouping to pairs using arithmetic averages (UPGMA - "Unweighted pair - group method using arithmetic average"), which aggrupates individuals according to their similarity.

\section{PURIFICATION OF THE BANDS}

The unique polymorphic bands visualized at the bulks were cut from the gel with a scalpel and put in a microtube of $1.5 \mathrm{ml}$. The purification occurred by the elution of the DNA in a microtube with three microholes and glass cotton at the bottom, and centrifugation for $5 \mathrm{~min}$ utes at 5,000 rpm. 1/10 of the volume of ammonium acetate $7.5 \mathrm{M}, 2$ volumes of cold ethanol $100 \%$, and $10 \mu \mathrm{L}$ of glycogen $(20 \mathrm{mg} / \mathrm{mL})$ to the centrifuged liquid, for overnight precipitation at $-20^{\circ} \mathrm{C}$. The solution was centrifuged for 15 minutes at $13,000 \mathrm{rpm}$, rejecting the supernatant and the precipitate washed with ethanol $70 \%$, centrifuged again at $13,000 \mathrm{rpm}$ during 5 minutes and re-suspended in $15 \mu \mathrm{L}$ of milli-Q water.

\section{Cloning of the Amplified Polymorphic Fragments}

The cloning of inserts of interest was done with the pGEM ${ }^{\circledR}-T$ Easy Vector Systems I (Promega) kit, following the manufacturer's recommendations.

Purification of the Plasmid Containing the InSERT

The extraction of the DNA was done according to the Perfectprep ${ }^{\circledR}$ Plasmid Mini (EPPENDORF) kit, following the manufacturer's protocol.

\section{ReACtion OF SEQUenCING IN Microtubes}

Positive clones were sequenced in both directions in MegaBaceTM 1,000 (Molecular Dynamics, Amersham Life Sciences), using the dideoxi sequencing method with universal primers M-13 forward and M-13 reverse, according to the manufacturer's recommendations. 
TABLE I

Primers used for the PCR reactions for the obtainment of RAPD markers.

\begin{tabular}{|c|c|c|}
\hline Primers & $\begin{array}{l}\text { Access } \\
\text { number }\end{array}$ & Nucleotides' sequency \\
\hline APO1 & 1 & 5'CACGGTCTGAGCTGATTGCGTGTTCTC 3' \\
\hline $\mathrm{APO} 2$ & 2 & 5'CCСТCСАAAATCAAGTGG 3' \\
\hline APO4 & 3 & 5'AAGTGCTGTAGGCCATTTAGATTAG 3' \\
\hline OPA1 & 4 & 5' CAGGCCCTTC 3' \\
\hline OPA2 & 5 & 5' TGCCGAGCTG 3', \\
\hline OPA3 & 6 & 5' AGTCAGCCAC 3', \\
\hline OPA4 & 7 & 5' AATCGGGCTG 3', \\
\hline OPA5 & 8 & 5' AGGGGTCTTG 3', \\
\hline OPA7 & 9 & 5' GAAACGGGTC 3' \\
\hline OPA10 & 10 & 5' GTGATCGCAG 3' \\
\hline OPA11 & 11 & 5' CAATCGTCCGT 3' \\
\hline OPA12 & 12 & 5' TCGGCGATAG 3', \\
\hline OPA14 & 13 & 5', TCTGTGCTGG 3', \\
\hline OPA15 & 14 & 5' TTCCGAACCC 3 ' \\
\hline OPA19 & 15 & 5' CAAACGTCGG 3', \\
\hline OPA20 & 16 & 5' GTTGCGATCC 3', \\
\hline OPF18 & 17 & 5' TTCCCGGGTT 3' \\
\hline RCO01 & 18 & 5'GCGGTGACCCGGGA 3' \\
\hline OPC06 & 19 & 5' GAACGGACTC 3' \\
\hline OPC18 & 20 & 5' CTCACCGTCC 3' \\
\hline OPI06 & 21 & 5' AAGGCGGCAG 3', \\
\hline G7 & 22 & 5'AAGCCCGACGACCTCACCCGCAGTGC 3' \\
\hline B2 & 23 & 5'CTCGCGCCCGGGATGAAGGTCGTCTTCCXXCCGACGTCCCAGGTC3' \\
\hline AI & 24 & 5 ' TCGGAGGTCAAGTCC 3' \\
\hline $\mathrm{H} 2$ & 25 & 5'CTCTAAGCTTGTGACTCAGGCTGACAAATCAGTTGTC 3' \\
\hline OPD02 & 26 & 5' TGGCCACTGA 3, \\
\hline OPV3 & 27 & 5' CTCCCTGCAA 3' \\
\hline OPM16 & 28 & 5' GTAACCAGCC 3' \\
\hline OPW10 & 29 & 5, TCGCATCCCT 3, \\
\hline OPC 13 & 30 & 5'AAGCCTCGTC 3', \\
\hline OPC06 & 31 & 5' GAACGGACTC 3', \\
\hline OPC18 & 32 & 5, TGAGTGGGTG 3, \\
\hline OPI06 & 33 & 5 ' TGCCCAGCCT 3' \\
\hline E2 & 34 & 5'CAGAATTCGGAA(AG)TA(GT)ATGA(AG)GGGGTC3' \\
\hline CL & 35 & 5'ACCTGCAGGCATTCTCCAGAAT 3' \\
\hline MYR1 & 36 & 5'ACACTGGAACGACTGTTACGAG 3' \\
\hline MYR2 & 37 & 5'GGTAATAAGTTCACGAATGTTCATGG 3' \\
\hline MYR3 & 38 & 5'ACAACGCTARAMTCGGACCGATG 3' \\
\hline MYR4 & 39 & 5’TCTGAGTTGTGACGTCCATCG 3' \\
\hline PRIMER 1 & 40 & 5'CCATCCACCATCTCAGCATGATGAAA 3' \\
\hline PRIMER 2 & 41 & 5'GGTTACTAGTAGTGGGTTTGCTGG 3' \\
\hline PRIMER 3 & 42 & 5’TATCGGGCCCAACCCCGACAAT 3' \\
\hline PRIMER 4 & 43 & 5'CCTTGAAGCACTTCTGGGAATCAGA 3' \\
\hline PRIMER 5 & 44 & 5'CTGACCCTGCAAAGGTAGGCGTATTCACT 3' \\
\hline PRIMER 6 & 45 & 5’CTCCGGTCTGAACTCAGATCACGTAGG 3' \\
\hline PRIMER 7 & 46 & 5'AAACTGGGATTAGATACCCCACTAT 3' \\
\hline PRIMER 8 & 47 & 5'GAGGGTGACGGGCGGTGTGT 3' \\
\hline R3 & 48 & 5'TCGTGTATTCAAATTGGCA 3' \\
\hline G7 & 49 & 5' ACGGAAGT 3' \\
\hline G6 & 50 & 5' AATGCGGGCG 3' \\
\hline PRIMER 2 & 51 & 5'ACAGAATTCGCTGACCATCAATAAG 3' \\
\hline PRIMER 3 & 52 & 5’TATCGGGGCCCAACCCCGACAAT 3' \\
\hline PRIMER 4 & 53 & 5'TGTTGACTGGCGTGATGTAGTTGCTTGG 3' \\
\hline
\end{tabular}




\section{ANALYSIS OF THE IDENTITY IN GENETIC BANKS}

An analysis of the identity of sequenced fragments was done using the GenBank data base. The BLAST program (Altschul et al. 1990) was used for the alignment of the sequences obtained from the pequi with others already deposited at the specific bank of plants.

\section{RESULTS AND DISCUSSION}

The DNA standard obtained for the samples was of good quality, which favors the RAPD reactions.

The generated bands at the RAPD enabled the analysis of the genetic variability among the five studied populations (Figs. 4a and 4b).

Out of the 77 primers that were used (Table I), 53 presented a good standard of bands and were selected for the analysis of the results, among these 21 generated polymorphisms (APO1, APO4, G6, G7, MYR1, MYR4, OPA1, OPA3, OPA4, OPA5, OPA7, OPA12, OPA14, OPA15, OPA19, OPI06, P2, P3, P7, P8, R3), which enabled to distinguish the population of pequi without thorn from the population with thorn.

The observed markers were as much for the presence of bands in all populations with thorn and their respective absence in populations without thorn, as for the presence of bands in population without thorn and absence in other populations with thorn at the endocarp.

The data obtained based on the 53 primers generated 326 fragments of RAPD, which were submitted to the analysis of cluster generating the dendogram of genetic divergence among the populations (Fig. 5).

The populations with smaller genetic divergences are from Minas and Tocantins, presenting a difference of $25 \%$ among their genotypes. Minas and Goiás presented a divergence of $30 \%$, whereas these three regions with the Xingu region (population with thorn) presented a genetic divergence of about $37 \%$. The pequi populations without thorn from the Xingu region was genetically isolated from the others, presenting a divergence of about $53 \%$.

The molecular characterization of the genotypes is a tool of great importance for the programs of genetic improvement, once crossbreeds among individuals with a greater genetic diversity may contribute to the amplification in segregating populations, thus enabling a greater genetic gain (Mesmer et al. 1993).
Despite the high genetic similarity among the analyzed populations, it is suggested that the characteristic presence or absence of thorns at the endocarp is related to the genetic divergence of the populations. They may be caused by a punctual mutation or even by chromossomic differences between the individual without thorn and the population with thorn at the mesocarp.

The selection of bands for the purification was based on the polymorphisms detected on the five studied populations. The cloning and sequences of the fragments generated information about genetic differences (mutations) or conserved regions (monomorphisms) among individuals selected for the absence and presence of thorn at the endocarp. The sequences of the clones were deposited at the GenBank (Accesses numbers ET052997 until ET053017).

The analysis of BLAST of nucleotides (Table II) demonstrated that, in the population with thorn at the endocarp, the ET053010 clone was shown as similar to the Dofl gene of Zea mays, whereas in the population without thorn, the ET053000 clone was similar to the phosphinotricin acetyl transferase gene of Z. mays.

The DOF1 gene encompasses a group of transcription factors in plants, with a sequence of well-conserved aminoacids (Yanagisawa 1996) containing the AAAG sequence that forms a dominium in zinc finger, which is essential for the bond to DNA, this sequence is present at the polymorphism that was found and related to this characteristic in pequi. The DOF proteins are responsible for processes of expression of the regulation of luminosity, regulation of answers to stress, answer to the expression of phytohormones and control of the transcriptional tissue-specific activities (Baumann et al. 1999, Chen et al. 1996, Cavalar et al. 2007, Kang and Singh 2000, Kisu et al. 1998, Mena et al. 1998, Vicente-Carbajosa et al. 1997, Yanagisawa 2000, Yanagisawa and Sheen 1998, Zhang et al. 1995). In the corn, the DOF1 protein activates the transcription of the responsible promoters by the luminosity signal, including $\mathrm{C} 4$ plants with promoter of the photosynthetic gene of the phosphoenolpyruvate carboxylase (Yanagisawa 1996, Yanagisawa and Izui 1993). The super expression of DOF1 in Arabidopsis thaliana induces the genes involved at the carbon metabolism and increases the fixation of nitrogen under limiting conditions (Yanagisawa et al. 2004). 
$\begin{array}{llllllllllll}1 & 2 & 3 & 4 & 5 & 6 & 2 & 3 & 4 & 5 & 6\end{array}$

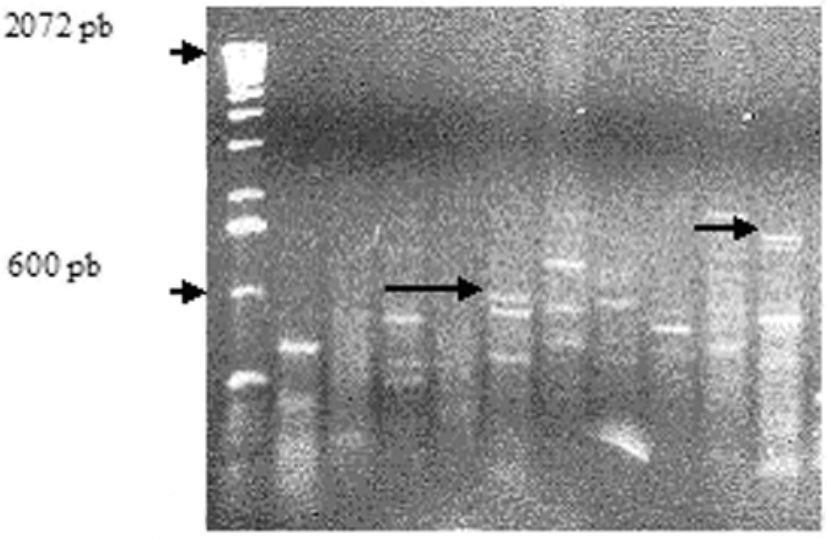

(A) $\begin{array}{lllll}6 & 5 & 4 & 3 & 2\end{array}$

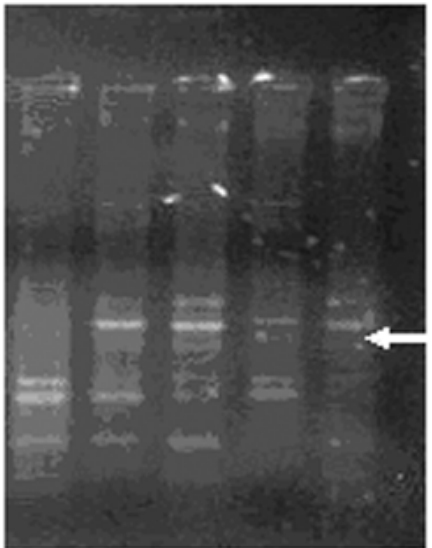

(B)

Fig. 4 - Products amplified by primers of RAPD (OPA3, OPA2 and OPA7, respectively). (A) 1 - marker (100 pb); 2 - Goiás; 3 - Minas Gerais; 4 - Porto Nacional; 5 - São José do Xingu (populations with thorn); 6 - São José do Xingu (populations without thorn) showing polymorphism in the pequi without thorns (black arrows). (B) Monomorphism in the pequi with thorn and absence of the band detected in the pequi without thorn (blank arrow). Agarose gel $2 \%$ colored with Ethidium Bromide.

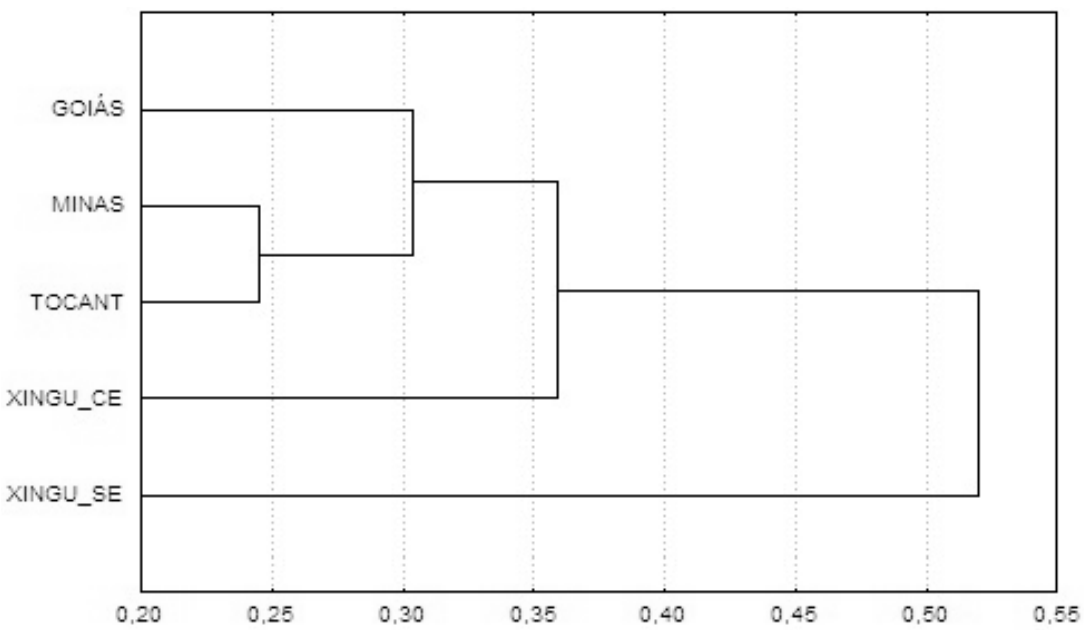

Fig. 5 - Representative dendogram of the genetic distance per percentage of disagreement and grouping by the UPGMA method among five populations of pequi (Caryocar brasiliense) of the Brazilian savannah using 53 primers. Goiás: Corumbaíba - GO (Fazenda Arrependidos); Minas: Uberlândia - MG (Clube Itororó Caça e Pesca de Uberlândia); Tocantins: Porto Nacional - TO; Xingu_CE: São José do Xingu - MT (pequi with thorn); Xingu_SE: São José do Xingu - Mato Grosso - MT (pequi without thorn).

The phosphinotricin acetyl transferase gene, with which the pequi sequence without thorn demonstrated similarity, catalyses the phosphinotricin acetylation, an analogous of glutamate, a herbicide that exercises the phytotoxic effect on the plants, inhibiting the glutamine synthetase (Hérout et al. 2005, Hoagland 1999, Gill et al. 2001).

The reason for the DOF1 to appear in the populations with thorn and the phosphinotricin acetyl transferase to express in the pequi without thorn is unknown. 
TABLE II

Analysis of Bioinformatics (BLASTn) of the selected clones, by RAPD, in Caryocar brasiliense (Camb.) with and without thorn at the endocarp.

\begin{tabular}{c|c|c|c}
\hline $\begin{array}{c}\text { Clone (number of } \\
\text { access to the } \\
\text { GenBank) }\end{array}$ & Similarity & Name & e-value \\
\hline $\begin{array}{c}\text { ET053010 } \\
\text { Population } \\
\text { with thorn }\end{array}$ & $\begin{array}{c}\text { Similar to } \\
\text { DQ490965.1 } \\
\text { (Zea mays) }\end{array}$ & $\begin{array}{c}\text { Clone pGR25C22 } \\
\text { disrupted DOF1 } \\
\text { (Dof1) gene }\end{array}$ & $5 \mathrm{e}^{-160}$ \\
\hline $\begin{array}{c}\text { ET053000 } \\
\text { Population } \\
\text { without thorn }\end{array}$ & $\begin{array}{c}\text { Similar to } \\
\text { DQ156557.1 } \\
\text { (Zea mays) }\end{array}$ & $\begin{array}{c}\text { phosphinothricin } \\
\text { acetyltransferase } \\
\text { gene }\end{array}$ & $1 \mathrm{e}^{-25}$ \\
\hline
\end{tabular}

TABLE III

Analysis of Bioinformatics (BLASTx) of the selected clones, by RAPD, in Caryocar brasiliense (Camb.) with and without thorn at the endocarp.

\begin{tabular}{|c|c|c|c|}
\hline $\begin{array}{l}\text { Clone (number of } \\
\text { access to the } \\
\text { GenBank) }\end{array}$ & Similarity & Name & e-value \\
\hline $\begin{array}{l}\text { ET053002 } \\
\text { Population } \\
\text { with thorn }\end{array}$ & $\begin{array}{c}\text { Similar to } \\
\text { NM_130140.2 } \\
\text { (Arabidopsis thaliana) }\end{array}$ & $\begin{array}{c}\text { CPFTSY } \\
\text { (ferric reductase } \\
\text { deficient 4) }\end{array}$ & $2 \mathrm{e}^{-22}$ \\
\hline $\begin{array}{c}\text { ET053011 } \\
\text { Population } \\
\text { without thorn }\end{array}$ & $\begin{array}{l}\text { Similar to } \\
\text { pir||A55092 } \\
\text { (Zea mays) }\end{array}$ & $\begin{array}{c}\text { Catalase } \\
\text { (EC 1.11.1.6) } \\
\text { CAT-2-maize } \\
\text { fragment }\end{array}$ & $1 \mathrm{e}^{-09}$ \\
\hline $\begin{array}{l}\text { ET053006 } \\
\text { population } \\
\text { with thorn }\end{array}$ & $\begin{array}{c}\text { Similar to } \\
\text { NM } 130140.2 \\
\text { (Arabidopsis thaliana) }\end{array}$ & $\begin{array}{c}\text { CPFTSY } \\
\text { (ferric reductase } \\
\text { deficient 4) } \\
\end{array}$ & $3 \mathrm{e}^{-11}$ \\
\hline $\begin{array}{c}\text { ET053012 } \\
\text { Population } \\
\text { without thorn }\end{array}$ & $\begin{array}{l}\text { Similar to } \\
\text { pir||A55092 } \\
\text { (Zea mays) }\end{array}$ & $\begin{array}{c}\text { Catalase } \\
\text { (EC 1.11.1.6) } \\
\text { CAT-2-maize } \\
\text { fragment }\end{array}$ & $2 \mathrm{e}^{-06}$ \\
\hline
\end{tabular}

The effect that these genes exercise in the pequi is unknown. The genomic markers developed in this paper will be able to contribute for an identification of the genetic causes of the absence of thorn in the endocarp in the restricted population of São José do Xingu. It is possible to search the metabolical way of these codified proteins in these genes, and their function in the obstruction of the appearance of thorn in the pequi.

The analysis of BLAST of proteins (Table III) demonstrated similarities of the ET053002 and ET052006 clones to the CPFSTY protein (deficiency in ferric reductase 4) of Z. mays in the pequi without thorn. The ET053011 and ET053012 clones presented similarity to the catalase protein of Arabidopsis thaliana in the pequi with thorn.
The plants with deficiency in iron induce the plasmatic membrane to link to the ferric reductase, which transfers electrons from the intracellular NADH or NADPH for $\mathrm{Fe}^{3+}$ in the rhizosphere (Buckhout et al. 1989, Sijmons et al. 1984). $\mathrm{Fe}^{2+}$ ions are subsequently liberated and conducted to the cytoplasm through transport proteins, inducing the acidification of roots, stimulated by the deficiency in iron (Kochian 1991, Fox et al. 1996, Cohen et al. 1997). Plants that grow in soils poor in iron are selected for adaptative mechanisms that increase the availability of iron in the rhizosphere (Inskeep and Bloom 1987). The adaptative answers of the roots differ according to the species. Non-gramineous dicotiledones and monocotiledones induce morphological and physiological differentiations of roots (Marschner and 
Romheld 1994, Schmidt 1999, Orturk et al. 2007). The increase in the capacity of the roots to reduce iron chelants by the induction of ferric reductase in the plasmatic membrane is another answer for the deficiency of iron; the reduction of $\mathrm{Fe}^{3+}$ in $\mathrm{Fe}^{2+}$ in the surface of roots is an obligatory process to the acquisition of iron in plants (Marschner and Romheld 1994, Robinson et al. 1999). The acidification of the rhizosphere contributes to the increase of solubility of iron available to plants (Marschner et al. 1986). Catalase is one of the antioxidant enzymes that degradate the oxygenated water (Scandalios et al. 1997). It performs an important role in the defense of the plant, aging and senescence. The catalase activity is influenced by acetylsalicylic acid and nitric oxide (Yang and Poovaiah 2002, Paterson et al. 1984). The balance between catalase and super-oxide dismutase is crucial in the determination of the level of $\mathrm{O}_{2}$ and $\mathrm{H}_{2} \mathrm{O}_{2}$ in the cell. The process of photo-oxidation during abiotic stress is common in plants, being able to cause cellular destruction and liberating reactive species of the oxygen such as the oxygenated water. (Foyer 1996). The super-reduction of the photosystem II (PSII) occurs when the assimilation of carbon is repressed during the environmental stress, and when the luminosity flow is elevated. In these states of excess of photons, the PSII becomes progressively reduced and leads the plant to an oxidative stress, producing free and possibly super-oxide oxygen (Krause 1994, Osmond and Grace 1995). In this sense, catalase acts with an antioxidant enzyme in the plants. The role of the protein responsible for the deficiency of ferric reductase and catalase is not known in Caryocar brasiliense. It can be suggested that the deficiency of iron in the roots leads the population without thorns to an environmental stress, repressing the production of thorns at the endocarp, whereas in the populations with thorn the presence of catalase prevents the oxidative stress and a repression of the thorns production does not occur.

\section{CONCLUSIONS}

From the analyzed primers of RAPD, it could be observed that there is a genetic divergence among the populations of pequi with and without thorn at the endocarp, and that the absence of thorn in the pequi might in part be due to differences in the metabolism route.
However, biochemical and genetic studies are needed to confirm these mechanisms.

\section{ACKNOWLEDGMENTS}

This study is part of the Doctoral thesis of the first author and received financial aid of Universidade Federal de Uberlândia, Conselho Nacional de Desenvolvimento Científico e Tecnológico (CNPq) and Coordenação de Aperfeiçoamento de Pessoal de Nível Superior (CAPES).

\section{RESUMO}

Pequi, Caryocar brasiliense, é uma das espécies de destaque no bioma do cerrado brasileiro, devido a sua utilização na medicina, na culinária popular, indústria em geral, e na do ferro e do aço. Na região de São José do Xingu (MT), uma árvore de pequi sem espinho no endocarpo foi encontrado e isso permite melhorar pequi não só para o consumo, aproveitando a alta apreciação que já possui. Para detectar as diferenças existentes entre o genoma de pequi com e sem espinho no endocarpo, marcadores moleculares RAPD foram utilizados. Os polimorfismos gerados foram clonados e sequenciados, a fim de identificar as sequências responsáveis pela alteração fenotípica. Observou-se que o pequi sem espinho é geneticamente isolado de outras populações de pequi com espinho no endocarpo, provando que essa característica está relacionada com a divergência genética da espécie. Análise em Blastn evidenciou a similaridade dos genes Dof1 e com o gene da fosfinotricina-acetiltransferase de Z. mays. Na análise da BLASTx, a similaridade foi verificada com as proteínas responsáveis pela deficiência de ferro 4 redutase e catalase.

Palavras-chave: Caryocar brasiliense, pequi, espinho, RAPD.

\section{REFERENCES}

AlENCAR G. 2000. Pequizeiros enfrentam riscos de extinção. Hoje em dia, 7 p.

Almeida SP AND Silva JA. 1994. Pequi e buriti: importância alimentar para a população dos cerrados. Planaltina: EMBRAPA-CPAC, (Documentos, 54), 38 p.

Almeida SP, ProençA CEB, SANo EM And Ribeiro JF. 1998. Cerrado: espécies vegetais úteis. Planaltina: EMBRAPA-CPAC, 464 p.

Altschul SF, Gish W, Myers EW AND Lipman DJ. 1990. Basic local alignment search tool. J Mol Biol 215: 403-410. 
ARAUJO FD DE. 1995. A review of Caryocar brasiliense (Caryocaraceae) an economically valuable of central Brazilian Cerrados. Economic Botany 49: 40-48.

BARRADAS MM. 1972. Informações sobre a floração, frutificação e dispersão do pequi (Caryocar brasiliense Camb.) (Caryocaraceae). Cienc cult 24: 1063-1068.

Baumann K, De PaOlis A, Costantino P And GualBERTI G. 1999. The DNA binding site of the Dof protein $\mathrm{NtBBF} 1$ is essential for tissue-specific and auxin-regulated expression of the rolB oncogene in plantas. Plant Cell 11: 323-333.

BRANDÃo M, LACA-Buendía JP ANd Macedo JF. 2002. Árvores nativas e exóticas do Estado de Minas Gerais. Belo Horizonte: EPAMIG, 528 p.

Buckhout TJ, Bell PF, Luster DG ANd ChANey RL. 1989. Iron-stress induced redox activity in tomato ( $L y$ copersicon esculentum Mill) is localized on the plasma membrane. J Plant Physiol 90: 151-156.

Cavalar M, Phlippen Y, Kreuzaler F and PeterHANSEL C. 2007. A drastic reduction in Dof 1 transcript levels does not affect C4-specific gene expression in maize. J Plant Physiol 164: 1665-1674.

Chen W, Chão G And Singh KB. 1996. The promoter of na $\mathrm{H}_{2} \mathrm{O}_{2}$-inducible, Arabidopsis glutathione S-transferase gene contains closely linkek OBF- and OBP1 binding sites. Plant J 11: 955-966.

Cohen CK, Norvell WA AND Kochian LV. 1997. Induction of the root cell plasma membrane ferric reductase. J Plant Physiol 114: 1061-1069.

CORNER EJH. 1976. The seeds of dicotiledons. Cambridge: Cambridge University 1: 311.

DOYLE JJ AND DOYLE JL. 1990. Isolation of plant DNA from fresh tissue. Focus 12: 13-15.

Fox TC, Shaff JE, Grusak MA, Norvell WA, Chen Y, Chaney RL and Kochian LV. 1996. Direct measurement of ${ }^{59} \mathrm{Fe}$-labeled $\mathrm{Fe}^{2+}$ influx in roots of pea using a chelator buffer system to control free $\mathrm{Fe}^{2+}$ in solution. $\mathrm{J}$ Plant Physiol 111: 93-100.

FOYER CH. 1996. Oxygen processin in photosynthesis. Biochem Soc Trans 24: 427-433.

Gill HS, Pfluegl GMU and Eisenbeg D. 2001. The crystal structure of phosphinothricin in the active site of glutamine synthetase illuminates the mechanism of enzymatic action. Biochemistry 40: 1903-1912.

Hérout C, Esdaile DJ, Mallyon BA, Debruyne E, Schulz A, Currier T, Hendrickx K, Klis R AND ROUAN D. 2005. Safety evaluation of the phosphinothricin acetyltransferase proteins encoded by the pat and bar sequences that confer tolerance to glufosinate-ammonium herbicide in transgenic plants. Regul Toxicol Pharm 41: 134-149.

HoAgland RE. 1999. Biochemical interactions of the microbial phytotoxin phosphinothricin and analogs with plants and microbes. In: CUTLER HG AND CUTLER SJ (Eds), Biologically active natural products: agrochemical. Boca Raton, FL: CRC Press, 107 p.

INSKEEP WP AND BLOOM PR. 1987. Soil chemical factors associated with soybean chlorosis in calciaquolls of western Minnesota. Agron J 79: 779-786.

KANG HG AND SINGH KB. 2000. Characterization of salicylic acid-responsive, Arabidopsis DOF domain proteins: over-expression of OBP3 leads to growth defects. Plant J 21: 329-339.

Kerr We, Silva FR da And Tchucarramae B. 2007. Pequi (Caryocar brasiliense Camb.). Informações preliminares sobre um pequi sem espinhos no caroço. Rev Bras Frutic 29: 169-171.

Kisu Y, Ono T, Shimofurutani N, Suzuki M AND ESAKA M. 1998. Characterization and expression of a new class of zinc finger protein that binds to silencer region of ascorbate oxidase gene. Plant Cell Physiol 39: 1054-1064.

KOCHIAN LV. 1991. Mechanisms of micronutrient uptake and translocation in plantas. In: MORTVEDT JJ, COX FR, Shuman LM AND Welch RM (Eds), Micronutrients in Agriculture, $2^{\text {nd }}$ ed., Soil Sci Soc Am J, Madison, WI, p. 229-296.

KRAUSE GH. 1994. The role of oxygen in photoinhibition of photosynthesis. In: FOYER CH AND MullineAuX PM (Eds), Causes of photooxidative stress and amelioration of defense systems in plants. CRC Press, Boca Raton, FL, p. 43-79.

LOPES PSN, SOUZA JC DE, REIS PR, OLIVEIRA JM AND RochA IDF. 2003. Caracterização do ataque da broca dos frutos do pequizeiro. Rev Bras Frutic 25: 540-543.

MARSChNer H AND Romheld V. 1994. Strategies of plants for acquisition of iron. Plant and Soil 165: 261274.

Marschner H, Romheld V And Kissel M. 1986. Different strategies in higher plants in mobilization and uptake of iron. J Plant Nutr 6: 695-713.

Mena M, Vicente-Carbajosa J, Schmidt RJ And CARBonero P. 1998. Na endosperm-specific DOF protein from barley, highly conserved in wheat, binds to and activates trasncription from the prolamin-box of a native $\beta$-hordein promoter in barley endosperm. Plant $\mathrm{J} 16$ : $53-62$. 
Mesmer MM, Melchinger AR, Hermann RR And BOPPERNMAIER J. 1993. Relationships among early European maize inbreeds: I. Comparasion of pedigree and AFLP data. Crop Science 33: 944-950.

Orturk L, Yazici A, Eker S, Gokmen O, Romheld V AND CAKMAK I. 2007. Glyphosate inhibition of ferric reductase activity in iron deficient sunflower roots. New Phytologist 177: 899-906.

Osmond CB AND Grace SC. 1995. Perspectives on photoinhibition and photorespiration in the field: quintessential inefficiencies of the light and dark reactions of photosynthesis? J Exp Bot 46: 1351-1362.

Paterson BD, MacRae EA And Ferguson IB. 1984. Estimation of hydrogen peroxide in plant extracts usin titanium (IV). Anal Biochem 139: 487-492.

Ribeiro AE. 1996. O espaço, o homem e o seu destino no norte de Minas. In:Universidade FEDERAL DE LAVRAS. Departamento de Administração e Economia. Manejo sustentado do cerrado para uso múltiplo: subprojeto agroecologia e desenvolvimento. Lavras, p. 89-152.

Robinson NJ, Procter CM, Connolly EL AND GueRINOT ML. 1999. Aferric-chelate reductase for iron uptake from sils. Nature 397: 694-697.

Santos BR, PAiva R, Dombroski JLD, MartinotTo C, Nogueira RC And Silva AAN. 2007. Pequizeiro (Caryocar brasiliense Camb.): uma espécie promissora do cerrado brasileiro. $<$ http://www.editora.ufla.br/Boletim/pdf/bol_64.pdf > . Accessed on: Sept 3, 2007.

ScAndalios JG, GuAn LM And Polidoros A. 1997. Oxidative Stress and the molecular biology of antioxidant defenses. In: ScAndalios JG (Ed), Cold spring Harbor Lab. Press, Plainveiew, NY, p. 343-406.

SCHMIDT W. 1999. Mechanisms and regulation of reductionbased iron uptake in plants. New Physiology 141: 1-26.

SiJMONS PC, VAN DER BRIEL W AND BIENFAIT HF. 1984. Cytosolic NADPH is the electron donor for extracellular $\mathrm{Fe}(\mathrm{III})$ reduction in iron-deficient bean roots. J Plant Physiol 75: 219-221.
Vicente-CARbajosa J, Moose SP, PARsons E AND SCHMIDT RJ. 1997. A maize zinc-finger protein binds the prolamin box in zein gene promoters and interacts with the basics leucine zipper transcriptional activator Opaque2. Proc Natl Acad Sci USA 94: 7685-7690.

Williams JGK, KUBELIK AR, LiVAK KJ, RAFALSKi JA AND TINGEY SV. 1990. DNA polymorphisms amplified by arbitrary primers are useful as genetic markers. Nucleic Acid Res 18: 6531-6535.

YANAGISAWA S. 1996. DOF DNA binding proteins contain a novel zinc finger motif. Trends Plant Sci 1: 213-214.

YANAGisawa S. 2000. Dof1 and Dof2 transcription factors are associated with expression of multiple genes involved in carbon metabolism in maise. Plant J 21: 281-288.

YANAGISAWA S AND IZUI K. 1993. Multiple interactions between tissue-specific nuclear proteins and the promoter of the phosphoenolpyruvate carboxylase gene for $\mathrm{C} 4$ photosynthesis in Zea mays. Mol Gen Genet 224: 325-332.

YANAGISAWA S AND SHEEN J. 1998. Involvement of maize Dof zinc finger proteins in tissue-specific and light-regulated gene expression. Plant Cell 17: 209-214.

YANAGisawa S, AKIYAMa A, KisAKa H, UCHIMIYA H AND MiWA T. 2004. Metabolic engineering with Dof1 transcription factor in plants: Improved nitrogen assimilation and growth under low-nitrogen conditions. Proc Natl Acad Sci USA 10: 10.

YANG T AND PoovaiAh W. 2002. Hydrogen peroxide homeostasis: activation of plant catalase by calcium/calmodulin. PNAS 99: 4097-4102.

Zhang B, Chen W, Foley RC, Buttner M and Singh KB. 1995. Interactions between distinct types of DNA binding protein enhance binding to ocs element promoter sequences. Plant Cell 7: 2241-2252. 